\title{
State-sponsored Health Plan
}

National Cancer Institute

\section{Source}

National Cancer Institute. State-sponsored Health Plan. NCI Thesaurus. Code C157360.

Health insurance programs that are run and funded at the state level. 